\title{
Potency and Prospect of Halal Market in Global Industry: An Empirical Analysis of Indonesia and United Kingdom
}

\author{
Abdul Hamid ${ }^{1}$, Muhammad Said ${ }^{1} \&$ Endah Meiria $^{1}$ \\ ${ }^{1}$ State Islamic University Syarif Hidayatullah Jakarta, Indonesia \\ Correspondence: Abdul Hamid, State Islamic University Syarif Hidayatullah Jakarta, Indonesia.
}

Received: March 25, 2019

doi:10.11114/bms.v5i2.4167

\author{
Accepted: April 10, 2019 \\ Online Published: April 25, 2019 \\ URL: https://doi.org/10.11114/bms.v5i2.4167
}

\begin{abstract}
This research aim to describe and prove the correlation and influence between market potency and market prospect to determine the appropriate strategy and policy for halal product market development in Indonesia compared with United Kingdom. The object of this research are total of potential consumer, percentage of buying consumer, average selling price, total of annual average consumption rate, profit estimation, and sales estimation of halal product market in each countries base on halal products and services into fiqh platform. This research use quantitative and qualitative method, which is in quantitative method using estimation of Fixed Effect Methods and the validity examined by AR and Jarque-Bera test. The result of this research find that sales in UK and RI are heavily dependent on changes in time and period in each Country indicated by PER_EFFECT, even though this analysis has used white heterocedasticity approach to eliminate that impact. Potentials and Prospects in the United Kingdom and the Republic of Indonesia have a positive and significant influence on Halal market and both countries have the same potential and prospective behaviour toward the Halal Market, although differing individual country and time or period.
\end{abstract}

Keywords: market potency, market prospect, halal market, halal product, fiqh platform

\section{Introduction}

Halal food has been existed for over 1,400 years ago, but only in the last few decades halal products become an eminent in worldwide. Globally, it is estimated that there are approximately 1.6 billion Muslims in the world's population in more than 100 countries and it is expected to reach 2.2 billion in 2030. Therefore, it is not surprising that market for halal products and services attracted a lot of attention (Halal Goes Global: International Trade Center, 2015).

Halal industry is very important for Muslim worldwide to ensure the hygiene, cleanliness, not endanger the health and well-made or well-produced, either to be consumed, used and purchased by consumers. Theoretically, "Halal" is possible to become a benchmark for quality, which specifically refers to anything that is allowed by Islamic Sharia and applied to any activity that done by humans (Bohari; Hin; and Fuad, 2013). From a business perspective, halal market is undoubtedly in offering many attractive opportunities. With more traditional markets that reached the saturation point, the emergence of a new market based on value and halal principle, creating a new paradigm of commercial value which in this case is dominated by food and beverage sector, and recently expanded into pharmaceutical sector, cosmetic, and personal care. An increasing of consumer awareness and the foresight of market players drive this on the opportunities and potency of this new market (Halal Goes Global: International Trade Center, 2015).

With the largest Muslim population, makes Indonesia as a potential market for halal products. The increasing of Muslim consumer awareness towards their religious obligation creates a huge demand for halal products, as a command to use halal products and avoid the forbidden things as it written in Al-Qur'an and Hadith. Overall in the global halal market, Indonesia itself is in the top ten ranks as the Top 15 Countries with GIE Indicator Score with Malaysia in the first place (State of Islamic Economy Report, 2016/2017). Indonesian government should be able to utilize this potency as the country's revenue, as well as London, The United Kingdom that compare in this study that have growth opportunity in halal market. Until now, Indonesia is still lagging behind in halal product market development in spite of being the largest consumer. It is because of the huge demand of halal products in the world is not accompanied by the support from Indonesian government. In addition, halal products in Indonesia has a number of issues such as in related to the coaching, training and mentoring to the business players (entrepreneurs) who do not fully understand the implementation of halal certification and its benefits for them in the future (Osmena Gunawan, Deputy of LPPOM MUI, 
Jul 11, 2016 tirto.id).

This research aim to describe and prove the correlation and influence between market potency and market prospect for halal product market development in Indonesia and United Kingdom. The object of this research are total of potential consumer, percentage of buying consumer, average selling price, total of annual average consumption rate, profit estimation, and sales estimation of halal product market in each countries.

This study is very significance to be conducted not only in terms of academic matter, but also expected to theoretically and practically contribute to develop halal market in these two countries. Apart from that, the result of the study is significance to trace the dynamics of the Islamic law in the global market industry.

\section{Literature Review}

\subsection{Fiqh Platform of Halal Market}

Market in Islam is a medium to help each other that have a strong foundation in Al-Qur'an and Sunnah of Rasulullah SAW, including Al-Baqarah verse 198 "laysa 'alaikum junah an tabtaghu fadhlan min rabbikum" (there is no harm you seek sustenance from your Lord). Surat An-Nisa verse 29 "illa an takuuna tijaaratan 'an taraadhin minkum..." (except with the way of trade that based on mutual fond among you...) (Haroen, 2000).

Another fiqh rules of Islamic market in which there are sale and purchase using "al ashlu fil mu'amalah al ibahah illa yadullu daliil "alaa tahriimiha." (the origin of everything is permitted unless there is a proof that forbid it (haram)) (Al Nadawy, 1999M). In another rule "aynamaa wujidti al mashlahah fa tsamma hukmullah" (where there is a mashlaha, there is a God's law) (MUI, 2006). "laa dharar wa laa dhirar" (not to be dangerous and also not to be danger to others) (Ramadan, p.47). Realization of market concept in Islam has three fundamental characteristics: the principles of justice, avoid forbidden activities, and notice on expediency aspect (Ali, 2008).

Other theory that support halal market expressed in the book of Ihya' Ulumuddin, where Al-Ghazali talk about barter and its issues, the importance of trading activity, the evolution of market, including the workings of demand and supply power in influencing prices. Al-Ghazali did not deny that profit is the main motive of trade, but he emphasize on business ethics and Islamic value. The real profit is the benefit that gained in the hereafter. He also suggested that there should be government's role in maintaining the security of trade lanes for the smooth trade and economic growth (Hamid, Dar Al Nadwah, p.306). In halal market, profit became one of the main motive in trade, not only seek for profit but also to establish the society in ethics of economic activity in accordance with the rules of Islamic value.

\subsection{Scientific Platform of Halal Market}

Halal market as a complex and fragmented puzzle are still fluctuating and evolving. The variables are based on the assumption of culture, habit and preference, different interpretation of Sharia law and the global food supply chain is adding to this complexity. To understand the growth and evolution of halal market, it is important to focus on the forces that drive this market in the future.

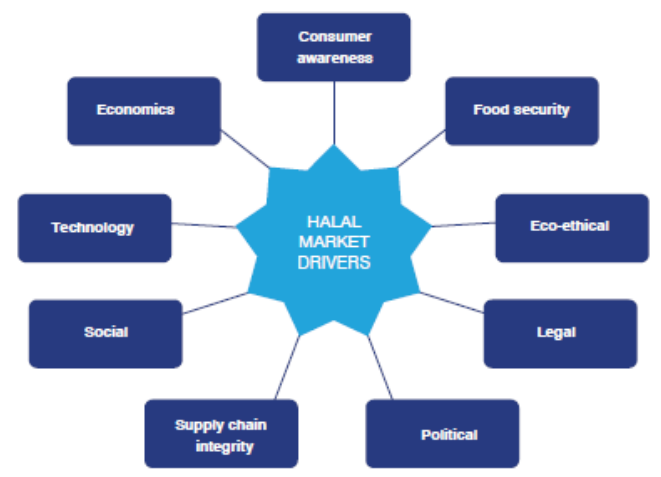

Figure 1. Key Drivers of Halal Market Growth (Halal Goes Global: International Trade Centre, 2015)

Based on the picture above, the key drivers of halal market growth are consumer awareness, economic, technology, social, integrated supply chain, politic, law, eco-ethical and food safety. If it mapped according to the PESTEL analysis (Political, Economy, Social, Technology, Environmental, Legal) then it will look as follows: 


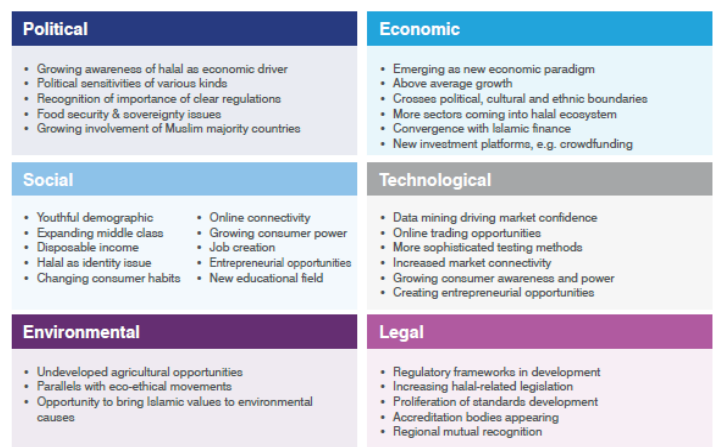

Figure 2. PESTEL Analysis of Halal Market (Halal Goes Global: International Trade Centre, 2015)

\subsection{Market Potency (MPo)}

Houston and Gassenheimer (1987) said that potency is unique, being personal to each entity. This one characteristic is the linchpin of marketing. By allowing exchanges to result in a greater value for each and every entity involved in an exchange, one entity's gain in potency is not at the expense of another entity's loss in potency. Potency, to use Alderson's term, is unique to the entity owning the assortment and can be characterized as intrinsic and/or extrinsic. A product or an assortment has extrinsic value if it derives its value from the marketplace, that is, it has exchange value. A product or an assortment has intrinsic value if it derives its value from some source other than the marketplace. Potency enhancement (or its companion, need satisfaction) is the motivating force behind those human behaviors we call "marketing".

\subsection{Market Prospect (MPr)}

Modern marketing theory teaches that the various segments available should be evaluated so the companies know which segment that can be served well (Kotler and Amstrong, 2010), and the target of sales and profits can be achieved. Despite the potential and bright prospect of halal products to the economy and to the halal products industry in particular, this sector faces numerous issues and challenges. Hence, the aim of this article is to highlight the opportunities as well as the main issues and challenges that halal products would be facing in striving to achieve the Halal market status.

The main question is that whether or not these opportunities outweigh the challenges to attract more halal market to provide Islamic products and services to these niche customers. The halal economy, which is rapidly expanding, offers opportunities not only to Indonesia but also to other Muslim countries worldwide. This will ensure that the halal concept can be applied to more than just the food sector. In addition to the manufacture, processing and distribution of products, additives and food ingredients, halal economy also applies to medicines, cosmetics and personal care products, clothes and services that include banking, finance, hotels, restaurants and even logistics. The population of Muslims stresses the enormous potential waiting to be tapped in the halal economy.

The future prospects of Halal market in Indonesia looks very exhilarate. It is envisaged that the growth of Halal market in Indonesia will be more encouraged. Several studies of halal food industry which has been done by many researchers such as Ananda (2008), HDC (2008), Chang (2007), Rahman (2007), Raja Adam (2006), Ramli (2006), Seong and Rizal (2006) and Riaz and Chaudhry (2004). Most researchers tend to have a positive outlook on the prospects of halal food products in the future. In addition, Nurwahida and Abdul Manaf (2009), Sungkar (2008), and Yusof (2004) are very optimistic that the halal food industry will continue its success when give the proper incentives and get support from government and industry players market. Globally, in 2015 the world total consumer spending on food and beverages are generally of US\$7,049 billion. Muslim consumer expenditure themselves for food and drinks reached US\$ 1,173 billion and is estimated to reach US\$1,914 billion in 2021. Meanwhile, revenue from halal-certified food and beverage products reach US $\$ 415$ billion (State of the Global Islamic Economy Report 2016/2017). These numbers constitute a justification of the halal market researchers and prove how big the potency and prospects of halal market in product and service sectors.

\subsection{Potency and Prospect of Halal Market}

This paper based on a relationship of mutual need between consumers and suppliers are expected to set the total number of potential customers who have a positive and significant correlation in marketing the halal market. Potential consumers are expected to reveal the Total Available Market (TAM), which is the whole of the available market share. It also expected to show the market share represented by Serviceable Available Market (SAM), which is the number of potential prospects that can be achieved by assuming that there are no other competitors. This variable is expected to have a positive and significant correlation to the halal market. In addition to disclose and describe the level of competition faced by the company average selling price required variables that have a positive and significant 
correlation with the halal market. The last variable in potency is the average annual consumption market. This variable is expected to describe Servicable Obtainable Market (SOM), which indicates the potential prospects that can reach or obtained by considering the competition. This variable is expected to have a positive and significant correlation with halal market. All of the above variables are expected to prove and illustrate market sizing which reveals the process of estimating the potential market, and understand the importance of market potency for companies who want to launch new products or services.

This paper argued that by halal market, all the total amount of sales based on consumer satisfaction can be achieved, so it needs to be collated and stipulated the projected sales and profit in the interest of consumers, and both have positive and significant correlation to the halal market. Calculations that commonly used in determining the level of profit and sales levels are ROI (Return on Investment), ROS (Return on Sales), RONA (Return on Net Asset), and ROCE (Return on Capital Employed).

\section{Research Methodology}

\subsection{Data Source and Methodological Framework}

This research used two methods: quantitative and qualitative methods. In quantitative methods, the examinations are expected to describe and prove the existence of potency and prospects in halal market based on hypotheses. The conceptual maps of this research as seen as follows:

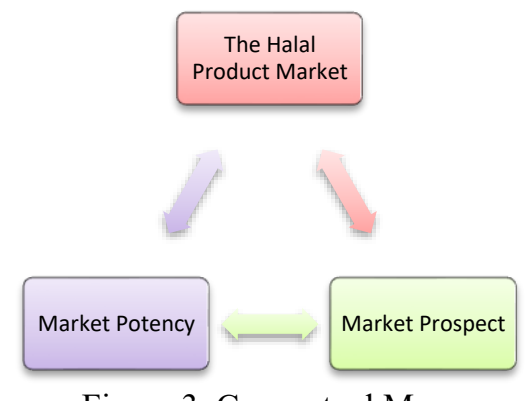

Figure 3. Conceptual Maps

Halal product market is expected to show and prove the correlation and influences between market potency and market prospect among each other.

This research considers two different countries, namely: Indonesia and United Kingdom. This research use (without consolidation) financial data, market data and marketing, as well as the macroeconomic data of each country that obtained from Thompson Reuter or Bankscope, and other data sources. The data which processed in this research is the information such as: the number of potential consumers, the number of regular customers, the selling price, the consumption rate per country, the profit rate, and the sales rate per sector in each country. Data period in this research includes the provided data from 2007 until 2017. The study was limited in the short-term period.

The fixed effect model (RE) is applied in this study. Under the pooled OLS regression is also estimated to compare the OLS results with the fixed effect model (FE). The FE model does not need to assume that the error component is not correlated with independent variables that may be difficult to meet.

\subsection{Assumptions}

Before running data from both countries (UK and RI) for the period 2007 to 2017 as the object of this study, then the first is determined the assumptions:

1) To know the behaviour of Halal market empirically and theoretically through the measurement of potential and prospect, Halal market data is proxies with Total Sales variable of all halal commodity items according to Sharia, not for commodities containing alcoholic beverages, tobacco, and narcotics.

2) The intercept between the two countries certainly differs individually (characteristic, culture, managerial style, incentive system, etc.), as well as differences in time, so that the fixed effect approach is used.

\section{Research Result}

The panel data set covers 11-year period from 2007 to 2017, with a sample of 2 Country are United Kingdom and Indonesia. The data were taken from the Thomson Reuters \& EIKON sources. The basic estimation strategy is to pool the observations and apply the regression analysis on the pooled sample. This paper does not include all dimensions of the market potency, market prospect and internal factors but limited to the following variables, that is, a pooled OLS (POLS) equation will be estimated in the form of: 


$$
Y_{i t}=\beta_{0}+\beta_{1} X 1_{i t}+\beta_{2} X 2_{i t}+u_{i t}
$$

Where :

$Y_{i t}$ is The Halal Market represents Total sales for country $i$ at time $t$. The variables are normalized by total sales that reported on all item of commodities such as; food and non-alcoholic beverages, housing, water, energy \&fuels, recreation \& culture, clothing \& footwear, furniture, household equipment \& main tenant, miscellaneous goods \&services, health, transport, communication, restaurant \& hotels, education. This proxy is supported by the rule of fiqh muamalah about the sale, products and services of halal that is "al ashlu fil mu'amalah al ibahah illa yadullu daliil 'alaa tahriimiha." (the origin of everything is permitted unless there is a proof that forbid it (haram)) (Al Nadawy, 1999). Another rule that supports this proxy is "maa harama fi'luhu harama thalabuhu" (for any forbidden object it is also forbidden for effort in getting it). Another rule in fiqh mu'amalah is "ad-dharuratu yuzaal" (the detriment must be eliminated).

$X 1_{i t}$ is the component of Halal market potency that describes the information of market availability, market share, competition, and consumption rate. The variables tested by using Total of potential consumer that represent total available market as a total market demand for product and service calculated by using total population. This variable is supported by the rule of fiqhmuamalah is "laa tadzlimuuna wa laa tudzlamuun" (should not tyrannize and be tyranny). Another theory that supports this variable from Ibnu Qayyim in his book I'lam Al Muwaqi'iin (1995, vol.3 p.14) states that the basis of Sharia is the wisdom and blessings of human in the world and in the Hereafter. This "mashlahah" lies in perfect justice, grace, prosperity and wisdom. Anything that makes justice an act of persecution, grace becomes violence, ease becomes a difficulty and wisdom becomes ignorance, then it has nothing to do with the Sharia.

$X 2_{i t}$ is a market prospect that will be tested by using forecasting from total of profits and revenues to obtain the picture of market growth and market size will be achieved. The variable is a component of Halal market shown by total income population as the objective to forecasting profit in sales. Therefore, for measurement to achieve profit based on consumer interest because of having money then used the income of the population. This proxy is supported by the rules of fiqh muamalah that support to get halal income that is every transaction must have the concept of "an taraadhin minkum" (must be mutually pleased with each other). $u_{i t}$ is random error.

\section{Results and Estimation:}

The current section deals with the results of the study that include the descriptive statistics, econometric results of the model, and tests for robustness relevant for the study. The empirical evidence on the determinants of potency and prospect Halal market are based on balanced panel data, where all the variables are observed for each cross-section and each time period.

The descriptive statistics shows that the variables used in our analyses for United Kingdom and Indonesia. Based on the first measure of Sales, the United Kingdom is smaller than Indonesia. The descriptive statistics for explanatory variables for UK and RI show that they are different. For example, the reported mean for income rate, season, weather, language, physical, etc.

In the UK, Muslims make around 5 per cent of the population and consume a Halal product, that's why many superstores have started their Halal offerings. This leads to an important market fact that non-Muslims not only come across Halal offerings in these mainstream supermarkets but also show/develop a particular behaviour towards these Halal products and services (Ayyub, 2015). The rapid growth of halal shops and other businesses in London mirrors the wider growth of ethnic minority businesses in the UK. Many also see the increasing Muslim population in the UK and Europe as encouragement to invest in such businesses and industries. There is a desperate need for new suppliers to meet the growing demands of schools, hospitals, hostels, prisons, airlines, restaurants, take-away and halal food supermarkets for Halal Market, packed meat and other halal consumable items, in all areas of the country. Also, there are expanding export markets to other European countries, such as France, Belgium, Holland and Germany (latest statistics estimate that there are 35 million Muslims in Europe) (Ahmed, 2008).

The perception of halal plays an important role in influencing purchasing behaviours. Variables such as manufacturer identity, product label, physicality of the product and its packaging and the country of origin have significant relationships with the perception of halal (Ishak, et.al., 2016). Though, the consumer behaviour is being affected by many factors, out of these, religion is considered an important one (Schiffman and Kanuk, 2009; Al-Hyari et al., 2012). Religion is considered a central cultural factor that has a major influence on people's attitudes, values and behaviours at both (individual and collective) levels (Mokhlis, 2009). In the multicultural world of the UK, religion has increased its impact on marketing activities and marketers must pay more attention towards religious aspects as well (Delener, 1994; Pettinger et al., 2004; Schlegelmilch and Oberseder, 2010) (Ayyub, 2015).

To non-Muslim the halal concept on food today is beyond the understanding of religious values alone. It represents hygiene, cleanliness and the quality of the food consumed (Mathew et. al., 2014). So that, when potency and prospect of halal market is increase, the availability of halal product is decrease instead. It is because people rolled out to this 
market and makes the products out of the stock. Not for the religion's value, but simply the value of the products that became standardization of good/health product.

The correlation among these variables for potency and prospect Halal Market in United Kingdom and Republic of Indonesia as suggested by Dougherty (2002) indicates a strong relationship between the variables between UK and RI. There is a perfectly negative correlation value occurs on the correlation between RI sales with all variables of potential and variables of prospects in UK and RI and the correlation of UK sales and RI sales are negative and weak. However, the results show that there is no multicolinearity problem among the independent variables used in the analysis in both samples. Therefore, all the variables were used in the analysis.

Yusanto and Widjajakusuma (2002, p.22-23) in his book "Initiating Islamic Business" state that Islamic motivation oriented to consumer buying behavior based on the hereafter, profit, benefit, sustainability and blessing. Another supporting theory is Imam Al Ghazali in his book "Al Mustasyfa" (1937, p.139-140) that the main purpose of Sharia is to preserve human welfare which includes the protection of their faith, life, mind, descendants and possessions. Whatever guarantees the protection of these five things is mashlahah for humans and will be desired.

The behaviour of the consumer is influenced by the buyer's decision process. Buyer characteristics include four major factors: cultural, social, personal, and psychological. Relationships are drawn between the factors (and factor subparts) and the consumption purchases made by consumers. Because many of these factors are deep and long lasting in their effect, the marketing manager should pay special attention to acquiring information about them with respect to the organization's target markets (Kotler and Amstrong, 2006).

Indonesian consumers have a unique attitude, behaviour and decision-making process in evaluating and buying products. Indonesian society is a group that has a strong socializing level. The impact of this strong community level is enormous for marketing strategies especially in the context of market penetration, one of which is the halal market. One important strategy is the communication strategy. The process of communication using word of mouth to be very effective that helps the market penetration of a brand. Indonesian consumers also tend to have no plans. This is what makes Indonesia's consumer spending patterns relatively irregular and makes the buying process through impulse buying relatively high. This is what makes the products that must be consumed regularly and planned, is also experiencing difficulties (Irawan, 2012).

Table 1. Estimation Results for Panel Data Model and Pooled OLS Using Sales as Dependent Variable and Consumers and Income as Independent Variables with Fixed Effect Methods

Dependent Variable: SALES?

Method: Pooled Least Squares

Date: 09/12/17 Time: 11:46

Sample: 20072017

Included observations: 11

Cross-sections included: 2

Total pool (balanced) observations: 22

Cross-section weights (PCSE) standard errors \& covariance (d.f. corrected)

\begin{tabular}{|c|c|c|c|c|}
\hline Variable & Coefficient & Std. Error & $\mathrm{t}$-Statistic & Prob. \\
\hline $\mathrm{C}$ & 31.82356 & 39.37834 & 0.808149 & 0.4424 \\
\hline Potency? & $-5.39 \mathrm{E}-05$ & $2.23 \mathrm{E}-05$ & -2.417509 & 0.0420 \\
\hline Prospect? & $3.48 \mathrm{E}-05$ & $2.73 \mathrm{E}-05$ & 1.276152 & 0.2377 \\
\hline \multicolumn{5}{|c|}{ Fixed Effects (Cross) } \\
\hline $\mathrm{UK}-\mathrm{C}$ & -84.03872 & & & \\
\hline $\mathrm{RI}-\mathrm{C}$ & 84.03872 & & & \\
\hline \multicolumn{5}{|c|}{ Fixed Effects (Period) } \\
\hline $2007-\mathrm{C}$ & -1.879099 & & & \\
\hline $2008-\mathrm{C}$ & -0.309191 & & & \\
\hline $2009-\mathrm{C}$ & 2.965576 & & & \\
\hline $2010-\mathrm{C}$ & 3.426907 & & & \\
\hline $2011-\mathrm{C}$ & 2.405738 & & & \\
\hline $2012-\mathrm{C}$ & 0.379048 & & & \\
\hline $2013-\mathrm{C}$ & 2.827939 & & & \\
\hline $2014-\mathrm{C}$ & 3.899595 & & & \\
\hline $2015-\mathrm{C}$ & -6.749254 & & & \\
\hline $2016-\mathrm{C}$ & -2.832762 & & & \\
\hline
\end{tabular}


Table shows the estimation results of Equation (1) using UK and RI sample are presented in Table 1 using the Fixed-Effects model and OLS (ordinary least square) for and Sales rate as dependent variable. The output of estimate equation shows that there is a difference in the results of both independent variables (consumer and income) to sales, with the condition of variant errors that have been in consistency. The estimated coefficient of the Consumer is negative, and statistically, insignificant affects sales using fixed effect model at least at $1 \%$ level, while it is positive but insignificant using the Income.

The slope coefficient of Halal market to UK was found to have a negative and insignificant impact on Halal Market, while Halal market to RI has impact positive and insignificant. Estimation Model and coefficient of Halal Market in UK and RI are:

$$
\begin{aligned}
& \mathrm{Y}_{\mathrm{UK}}=-84.038+\text { PER_EFFECT }+26.435 \mathrm{X} 1_{\mathrm{UK}}+3.479 \mathrm{X} 2_{\mathrm{UK}} \\
& \mathrm{Y}_{\mathrm{RI}}=84.038+\text { PER_EFFECT }+26.435 \mathrm{X} 1_{\mathrm{RI}}+3.479 \mathrm{X} 2_{\mathrm{RI}}
\end{aligned}
$$

Model estimation based on equation (1) in determining the behaviour of potential and prospect to Halal market in United Kingdom and Republic of Indonesia, the following results are obtained:

1) Sales in UK and RI are heavily dependent on changes in time and period in each Country indicated by PER_EFFECT, even though this analysis has used a fixed effect method approach to eliminate that impact. In addition, the use of this method of consideration is the amount of time series data is greater than the amount of data cross section it $(\mathrm{T}>\mathrm{N})$ (Mendenhall, 2011).

2) Potentials and Prospects in the United Kingdom and the Republic of Indonesia have a positive and significant influence on Halal market is indicated by positive slope value of each country of 26,435 (Consumer) and 3,479 (Income).

\section{Conclusion}

Effects Specification

Cross-section fixed (dummy variables)

Period fixed (dummy variables)

R-squared

0.863839 Mean dependent var

7.088782

Adjusted R-squared

0.642576 S.D. dependentvar

6.077947

S.E. of regression

3.633697 Akaike info criterion

5.679505

Sum squared resid

105.6300 Schwarz criterion

6.373804

Log likelihood

-48.47455 Hannan-Quinn criter.

5.843061

F-statistic

3.904135 Durbin-Watson stat

2.765422

Prob(F-statistic)

0.030136

This study empirically investigated the determinants of potency and prospect for Halal Market in United Kingdom and Republics of Indonesia countries during the period 2007-2017, using a cross-sectional time-series (panel data). Sales rate is dependent variables, and potential consumer (population) and Income rate (as profit estimation) are independent variables that used in this study. Increasing demand for Halal Market around the world, especially in UK and RI countries provides motivation for the study. The results show that potency and prospect are important in explaining and increasing Halal market, although there are differences in characteristics, culture, physical, and time in each country. The intercept on UK equation model shows negative but has been found to have a positive and insignificant impact on Halal market. It is important for both of countries to always initiate, socialize and implement the Halal market positively. Additionally, the positive and insignificant effect of Halal market provides evidence of Halal market is known to the public but have not the understanding about the advantages of Halal for life and hereafter. However, the coefficient of Consumer was found to have a negative and insignificant impact on Sales (Halal market).

Population and Income rate have no significant impact on Halal market for both countries. The evidence suggests that consumer (population) does not participate in improving Sales (Halal market) for both countries. The Income rate (prospect) variable was found to have a positive and insignificant impact on Sales (Halal market). Finally, with respect to the independent variables, both potency (Potential consumer) and prospect (Income rate) clearly affect Sales rate (Halal Market). The Consumer is positively correlated to Sales Halal, and Income is positively correlated to Sales Halal. 
This finding provides evidence of a strong relationship between potency and prospect (variables) and Sales of Halal Market. Overall, the empirical results provide the evidence that Sales of Halal rate for both countries affected by potential consumer (potency variables) and Income rate (prospect variables).

\section{References}

Ahmad, M. (1995). Business Ethics In Islam. IIIT. Islamabad.

Ahmed, A. (2008). Marketing of Halal Meat in UK: Supermarket versus Local Shops. British Food Journal, 110(7), Emerald Group Publishing Limited. https://doi.org/10.1108/00070700810887149

Alderson, W. (1957). Marketing Behavior and Executive Action. Homewood, IL: Richard D. Irwin, Inc.

Alderson, W. (1958). The Analytical Framework for Marketing reprinted in Marketing Theory, Stephen W. and Raymond P. Fisk. New York: John Wiley \& Sons, Inc., 45-53.

Ali Ahmad Al Nadawy, Mausu'ah Al Qawa'idwa Al Dhawabith Al Fiqhiyyah, (t.t: t.p.1419H/1999M)

al-Nawawi, Imam (nd) Riyadhus-Saleheen Trans., S. M. M. Abasi, IIPH, Riyadh.

al-Qur'an -English translation and commentary (The Meaning of the Glorious Qur'an) rendered by Abdullah Yusuf Ali (1983), Maryland (USA): Amana Corporation.

Al-Razi, M. (1985). TafsirFakhr al-Razi.3 ${ }^{\text {rd }}$ edition, Dar al-Fikr, Beirut.

Ananda S. (2008). Global Halal Presence. Business Today, 8(6), Reach Publishing.

Anas, M. (1989). Muwatta Imam Malik - The First Formulation of Islamic Law, Translated by Aisha Bewley, Kegan Paul International, London.

Arndt, J. (1983). The Political Economy Paradigm: Foundation for Theory Building in Marketing. Journal of Marketing, 47,44-54. https://doi.org/10.1177/002224298304700406

Ayyub, R. M. (2015). Exploring Perception of Non-Muslim towards Halal Foods in UK. British Food Journal, 117(9), Emerald Group Publishing Limited. https://doi.org/10.1108/BFJ-07-2014-0257

Baron, D. P. (1997). Integrated strategy, trade policy, and global competition. California Management Review. Berkeley: Winter, 39(2), 25,145. https://doi.org/10.2307/41165891

Barone, M. J., \& DeCarlo, T. E. (2003). Emerging forms of competitive advantage: Implications for agricultural producers. Midwest Agribusiness Trade Research and Information Center Research Paper 03-MRP 5.

Blundell, R., \& Bond, S. (1998). Initial conditions and moment restrictions in dynamic panel data models. Journal of Econometrics, 87, 115-143. https://doi.org/10.1016/S0304-4076(98)00009-8

Bohari, A. M., Hin, C. W., \& Fuadz, N. (2013). An Analysis on the Competitiveness of Halal Food Industry in Malaysia; An Approach of SWOT and ICT Strategy. Malaysia Journal of Society and Space, 9(1).

Brax, S., \& Jonsson, K. (2009). Developing integrated solution offerings for remote diagnostics. International Journal of Operations \& Production Management, 29(5), 53-60. https://doi.org/10.1108/01443570910953621

Carlson, L., Stephen, G., \& Norman, K. (1993). A Content Analysis of Environmental Advertising Claims: A Matrix Method Approach. Journal of Advertising, 22 (3), 27-39. https://doi.org/10.1080/00913367.1993.10673409

Chang, J. (2007). Malaysia Market Development Reports World Halal Forum and Malaysia's Role. Global Agriculture Information Network (GAIN) Report, MY7021.

Coddington, W. (1993). Green Marketing. New York: McGraw Hill.

Davies, A., \& Brady, T. (2000). Organizational capabilities and learning in complex products systems: toward repeatable solutions. Research Policy, 29, 931-53. https://doi.org/10.1016/S0048-7333(00)00113-X

Dess, G. G., Lumpkin, G. T., \& Taylor, M. L. (2005). Strategic Management (2 ed). McGraw-Hill Irwin, New York.

Dougherty, C. (2002). Introduction to econometrics. 2nd ed. New York: Oxford University Press.

Drumwright, M. E. (1994). Socially Responsible Organizational Buying: Environmental Concern as a Noneconomic Buying Criterion. Journal of Marketing, 58, 1-19. https://doi.org/10.1177/002224299405800301

DSN MUI, Himpunan Fatwa DSN MUI, (Cipayung-Ciputat: DSN. 1427H/2006M), Edisi Revisi, Cet. IV, h.VIII, IX.

Evans, N. (2003) The needs for enterprise innovation. [cited May 24, 2010]. Available from: http://www.informit.com.

Gebauer, H. (2008). Identifying service strategies in product manufacturing companies by exploring environment strategy configurations. Industrial Marketing Management, 37(3), 278-91. 
https://doi.org/10.1016/j.indmarman.2007.05.018

Gebauer, H., \& Friedli, T. (2005). Behavioral implications of the transition processfrom products to services. Journal of Business \& Industrial Marketing, 20(2), 70-8. https://doi.org/10.1108/08858620510583669

Gebauer, H., Fleisch, E., \& Friedli, T. (2005). Overcoming the service paradox in manufacturing companies. European Management Journal, 23(1), 14-26. https://doi.org/10.1016/j.emj.2004.12.006

Gustafsson, A., Nilsson, L., \& Johnson, M. D. (2003). The role of quality practices in service organizations. International Journal of Service Industry Management, 14(2), 232-44.

https://doi.org/10.1108/09564230310474183

Halal Goes Global, International Trade Center. (2015).

Haroen, N. (2000). Fiqh Muamalah. Jakarta: Gaya Media Pratama

Hart, S. (1995). A Natural-Resource-Based View of the Firm. Academy of Management Review, 20(4), 986-1014. https://doi.org/10.5465/amr.1995.9512280033

HDC (2008). HDC will be pro-business. The Halal Journal, 25. Available from: http://www.halaljournal.com/artman/publish/article_906.shtml.

Henion, K. E., \& Thomas, C. K. (1976). Ecological Marketing. Chicago: American Marketing Association.

Hidayatullah, S. (2012). Qawa'id Fiqhiyyah dan Penerapannya dalam Transaksi Keuangan Syariah Kontemporer (Mua'malat, Maliyyah Islamiyyah, Mu'ashirah). Jakarta: Gramata Publishing

Houston, F. S., \& Jule, B. G. (1987). Marketing and Exchange. Journal of Marketing, 51(4), 3-18. https://doi.org/10.1177/002224298705100402

Ibn, al-U., \& Diya' al-Din, M. (1983). Ma'alim al-Qurbah fi Ahkam al-Hisbah, Translated by Reuben Levy, Luzak, London.

Ibn, T. (1982). Public Duties in Islam: The Institution of the Hisbah, translated by Muhtar Holland, The Islamic Foundation, Leicestershire.

Ibnu Majah, Sunan Ibnu Majah, (t.t.:Dar Al Fikr, t.th.)

Irawan, H. (2012). Karakter dan Perilaku Khas Konsumen Indonesia (Character and unique behavior of Indonesian consumer). Marketing.co.id

Jennings, D., \& Paul, Z. (1995). Ecologically Sustainable Organizations: An Institutional Approach. Academy of Management Review, 20(4), 1015-52. https://doi.org/10.5465/amr.1995.9512280034

Kassarjian, H. (1971). Incorporating Ecology Into Marketing Strategy: The Case of Air Pollution. Journal of Marketing, 35, 61-65. https://doi.org/10.1177/002224297103500310

Kotler, P., \& Armstrong ,G . (2010). Principles of Marketing $13^{\text {th }}$ ed., Pearson Prentice- Hall, Upper Saddle River,NJ

Kumar, N. (2006). Strategies to fight low-cost rivals. Harvard Business Review, 84, 104-12.

Labadie, B. (1991). Social Investing: Social Value and the Value of Money. Pension World, 27(10), 32.

Lodhi, S. A., Rukhsana, K., \& Mazhar, I. (2005). Strategic Directions for Developing an Islamic Banking System [with Comments]. The Pakistan Development Review, 44(4), Papers and Proceedings PART II, Twenty-first Annual General Meeting and Conference of the Pakistan Society of Development Economists Islamabad. pp. 1003-1020. https://doi.org/10.30541/v44i4IIpp.1003-1020

Majah, Ibnu. T.th. Sunan Ibnu Majah. Dar Al Fikr

Matthyssens, P., \& Vandenbempt, K. (2008). Moving from basic offerings to value-added solutions: strategies, barriers and alignment. Industrial Marketing Management, 37(3), 316-28. https://doi.org/10.1016/j.indmarman.2007.07.008

McDaniel, S., \& David, R. (1993). Strategic Green Marketing. Journal of Consumer Marketing, 10(3), 4-10. https://doi.org/10.1108/07363769310041929

Neu, W. A., \& Brown, S.W. (2005). Forming successful business-to-business services ingoods-dominant firms. Journal of Service Research, 8(1), 3-17. https://doi.org/10.1177/1094670505276619

Neu, W. A., \& Brown, S. W. (2008). Manufacturers forming successful complex business services. International Journal of Service Industry Management, 19(2), 232-51. https://doi.org/10.1108/09564230810869757

Niazi, L. A. K. (1996). Islamic Law of Contract. Lahore: Research Cell, Dayal Sing Trust Library. 
Oliva, R., \& Kallenberg, R. (2003). Managing the transition from products to services. International Journal of Service Industry Management, 14(2), 160-72. https://doi.org/10.1108/09564230310474138

Ql'ahJiy, R. (1987). Mausu'ah Fiqh Umar Bin Al Khattab, Beirut: Dar Al Nafais.

Rahman, L. (2007). Syariah and Malaysian Halal Certification System. Bengkel Audit Dari Perspektif Syariah, Bahagian Hub Halal. Jabatan Kemajuan Islam Malaysia

Raja, A. Z. (2006). RM100m boost to make Malaysia halal hub. Business Times.

Ramadhan, 'Athiyah.T.th. Mausu'ah Al Qawa'id Al Fiqhiyyah. Al Iskandariyah: Dar Al Qimmah-Dar Al Iman.

Ramli, N. (2006). Halal - The New Global Market Force. Legal Insights A Skrine Newsletter, Issue 2/2006, June 2006. [cited 21 May, 2006]. Available from: http://www.skrine.com/get.php.

Riaz, M. N., \& Chaudry, M. M. (2004). Halal food production. CRC Press LLC, Florida. https://doi.org/10.1201/9780203490082

Saeed, M., Ahmad, Z. U., \& Mukhtar, S. M. (2001). International Marketing Ethics from an Islamic Perspectives: A Value Maximization Approach. Journal of Business Ethics, 32, 127-142; Salesperson Selling Behaviors on Customer Satisfaction with Products. Journal of Retailing, 73(2), 171-183. https://doi.org/10.1016/S0022-4359(97)90002-6

Seong, L. W., \& Rizal, M. A. W. (2006). The Potential of Halal Industry in Penang. Penang Economic Monthly, 8(11).

Sheth, J., \& Atul, P. (1995). Ecological Imperatives and the Role of Marketing. Environmental Marketing: Strategies, Practice, Theory, and Research. Michael Jay Polonsky and Alma T. Mintu-Wimsatt, eds. New York: Haworth Press, 3-20.

Shrivastava, P. (1994). Castrated Environment: Greening Organization Studies. Organization Studies, 15 (5), 705+ (1995a). The Role of Corporations in Achieving Ecological Sustainability. Academy of Management Review, 20 (4), 936-60. (1995b). Environmental Technologies and Competitive Advantage. Strategic Management Journal, 16, 183-200. https://doi.org/10.1177/017084069401500504

State of Islamic Economy Report (2016/2017).

Sungkar, I. (2008). The Global Trends and Halal Trade Issue. The Halal Journal.

Trim, B. (2008). Business Wisdom of Muhammad SAW: 40 Kedahsyatan Bisnis ala Nabi SAW (Business Wisdom of Muhammad SAW: 40 Business breakthrough of prophet SAW), Madania Prima, Bandung.

William, M. (2011). A Second Course in Statistics: Regression Analysis [7th (Seventh) Edition]. Prentice Hall.

Windmeijer, F. (2005). A finite sample correction for the variance of linear efficient two-step GMM estimators. Journal of Econometrics, 126, 25-51. https://doi.org/10.1016/j.jeconom.2004.02.005

Yusof, M. H. (2004). Halal Certification Scheme. Standard and Quality News, 11(4).

\section{Copyrights}

Copyright for this article is retained by the author(s), with first publication rights granted to the journal.

This is an open-access article distributed under the terms and conditions of the Creative Commons Attribution license which permits unrestricted use, distribution, and reproduction in any medium, provided the original work is properly cited. 